publications to those institutions which received the publications of the Royal Academy of the Lincei under a system of exchange.

\section{Chemical Club}

Tre Chemical Club, 2 Whitehall Court, London, S.IV.1, has arranged a series of 'talks' similar to those held at the Club last winter. They will, however, be briefer, and will be held after luncheon in view of the War. The first talk of the season will bo given by Mr. James Kowley, chief chemist of the Royal Dutch Shell Group, on Monday, December 11, at 2 o'clock at the Club. The title will be "The Intrusions of Petroleum", and it is oxpected to deal with the increased range of products being manufactured by tho petroleum industry which 'intrude' upon the organic chemical market. At the annual general meeting of the Club on November 14, a resolution was adopted that the facilities of the Club should be thrown open during hostilities, at a nominal subscription, to those temporarily engaged in London on Government work.

\section{Chadwick Public Lectures}

IN September last it was decided, in consequence of the War, to postpone the Chadwick Public Lectures which were to have been delivered this autumn. The Trustees have now resolved to resume the lectures, and the first lecture is to be delivered on Tuesday, December 12, at 2.30 p.m., at tho Royal Society of Tropical Medicine and Hygiene, 26 Portland Place, W.1, when Sir William Savage is to speak on "The Health Aspects of Canned Foods". The lectures for the spring programme, 1940, will deal generally with public health matters and the War, and will be announced in due course.

\section{National Institute of Sciences of India}

AT a meeting of the Council of the National Institute of Sciences of India, held on October 6 in the rooms of the Royal Asiatic Society of Bengal, Calcutta, the following were elected fellows of the Institute: Ordinary Fellows: Dr. K. Banerjeo, reader in physics, University of Dacca; Prof. F. R. Bharucha, professor of botany and head of the Department, Royal Institute of Science, Bombay; Dr. R. N. Ghosh, reader in physics, University of Allahabad; Prof. H. K. Mookerjee, University professor of zoology and head of tho Department, University of Calcutta; Prof. V. V. Narlikar, professor of mathematics and head of the Department, Benares Hindu University ; Dr. C. G. Pandit, officiating director of the King Institute of Preventive Medicine, Guindy, Madras ; Major C. L. Pasricha, professor of pathology and bacteriology, School of Tropical Medicine, Calcutta; Prof. L. Rama Rao, professor of geology, University of Mysore; Dr. M. Sharif, entomologist, Haffkine Institute, Bombay; Dr. K. Venkataraman, director of the University of Bombay Laboratories of Chemical Technology and Textilo Chemistry. Honorary Fellows : Dr. E. V. Appleton, secretary of the Department of Scientific and Industrial Research of Great Britain; Prof. Charles W. Edmunds, professor of pharmacology and therapeutics, University of Michigan Medical School; Prof. R. A. Fisher, Galton professor of eugenics in University College, London; Prof. Waldemar Lindgren, emeritus pro. fessor of geology, Massachusetts Institute of Technology, whose death on November 3 is announced on p. 970 .

\section{Royal Society Officers and Council}

The following is a list of thoso elected as officers and council of the Royal Society at the anniversary meeting held on November 30 : President, Sir William Bragg; Treasurer, Prof. T. R. Merton; . Secretaries, Prof. A. V. Hill, Prof. A. C. G. Egerton; Foreign Secretary, Sir Albert Seward; Other Members of Council, Prof. F. C. Bartlett, Prof. P. G. H. Boswell, Prof. F. 'T. Brooks, Dr. C. G. Darwin, Prof. H. M. Fox, Dr. H. J. Gough, Dr. A. D. Imms, Prof. C. K. Ingold, Prof. G. B. Jeffery, Prof. R. T. Leiper, Prof. H. S. Raper, Sir Owen Richardson, Prof. E. K. Rideal, Dr. F. J. W. Roughton, Prof. W. W. C. Toploy, Prof. R. Whiddington.

\section{Announcements}

Dr. J. B. Mennel, president of the Section of Physical Medicine of the Royal Society of Medicine, has been awarded a gold key by the American Congress of Physical Therapy for distinguished research on physical therapy during the last year.

DR. ALFRED Froenulch, formerly professor of pharmacology in the University of Vienna, has been appointed pharmacologist to the May Instituto for Medical Research of the Jewish Hospital, Cincinnati.

The name of the National Baby Week Council, a body which camo into existence during the War of 1914-18, is now changed to "National Baby Welfare Council", this name being more commensurate with the increased scope of work falling to the Council's lot under war conditions. The address of the National Baby Welfare Council is 29 Gordon Square, London, IV.C.1.

THe Women's Medical Association of New York offers a Mary Putnam Jacobi fellowship to any woman doctor, American or foreign, to carry on or complete some special problems in medical research. Application should be made by March 1, 1940, to the secretary, Dr. Phebe L. Dubois, 150 East 73rd Street, Now York City.

In his latest quarterly report the Registrar-General states that the number of live births in England and Wales during the thirteen weeks ended June 30 was 222 more than in the corresponding quarter of 1938 , and amounted to an annual birth-rate of 16 per thousand of the population. The number of deaths corresponded to an annual rate of $11 \cdot 7$, and the mortality of infants under one year of age to an annual rate of 48 , which was 8 below the average of the preceding ten second quarters. 